\title{
A NEW CULICID GENUS RELATED TO CORETHRA.
}

BY D. W. COQUILLETT, WASHINGTON, D. C.

The genus Corethra was founded by Meigen in $1803, *$ on Tipula culiciformis, De Geer, and in April, 1844, Loew erected the genus Mochlonyx, fon Corethra velutina, Ruthe, basing it on the shortened first joint of the tarsi, a character mentioned by Ruthe in his original description. The characters of the tarsi of culiciformis cannot be ascertained from De Geer's description and figurest On page 386 of the same volume of his Memoires, which contains the account of this species, is a description and brief account of a related species, which he named Tipula crystallina, with a reference to Reaumur's Memoires, V., plate 6, figures $4^{-15}$, where, at 4 and 7 , a more slender larva without a trace of a subanal respiratory tube is shown, contrasting with the broader larva furnished with a large respiratory tube, as represented in De Geer's figures of culiciformis; the descriptions and figures which these authors give of crystallina do not indicate the characters of the tarsal joints of the adult. Thus matters stood at the time that Loew erected his genus Mochlonyx, and continued so until the year $188_{3}$.

In that year Dr. Fr. Meinert, of Copenhagen, published the results of his breeding of the adults from these two forms of larvæ, $\S$ asserting that the tubeless larva of crystallina produced an adult with elongated first tarsal joints as in Corethro in the sense of Loew, whereas the adult bred from the larva of culiciformis had the very short first tarsal joints of Mochlonyx. Some of the adults last mentioned were submitted to V. von Röder, of Hoym, Germany, an experienced dipterologist, who confirmed their reference to Mochlonyx, $\|$ adding that, with the exception of having the hairs on the abdomen and legs shorter, they are identical with Ruthe's species, two specimens of which were in his collection, received from Ruthe himself. It seems very certain, therefore, that the type species of

"Illiger's Magasin, II., p. 260. †Ent. Zeit. Stettin, p. I2I. 未Memoires, VI, p. 372, pl. 23, figs. 3-12. SOvers. Kon. Danske Vid. Selsk, Forh., pp. I-17, and Resume, pp. 7-II. "Entom, Nach., July, i 885 , p. 2 I 7 . 
Mochionyx, if not the same, is at least congeneric with that of Corethra; in other words, Loew applied the former name to the wrong division of Corethra, in consequence of which his proposed new generic name is a pure synonym of the latter.

Owing to the mistake of Loew, it will be necessary to give a new generic name to the group representing Corethra, Loew (not Meigen), and for this genus the name Sayomyia is proposed, in honour of the immortal Thomas Say; it will be readily recognized among the short-beaked Culicidæ by having the hairs of the antennæ gathered into whorls, the intervening spaces being almost bare, and by having the first tarsal joint longer than the second. The type species is Corthra punctipennis, Say.

The genus Corethra (= Mochlonyx) has not yet been reported from this country. Several years ago I received a specimen from Mrs. Annie T. Slosson, collected at Franconia, N. H., and later two more specimens were received from the same source, while in April of the present year the same species was detected at Mt. Vernon, Va., by Mr. W. V. Warner, of the U. S. National Museum. This species will readily be recognized by its banded legs and mottled wings, and may be characterized as follows: Corethra cinctipes, new species.

Blackish brown, the apices of the antennal joints except the last joint, the halteres, bases of the segments of abdomen in the male, base and under side of femora, a broad band near four-fifths of their length, their extreme apices, bases of tibia and a band near one-fourth of their length, also bases of the first three or four joints of the tarsi, yellow; hairs of male antennæ brown, their bases yellow, those at tips of antennæ almost wholly yellow; thorax grayish pruinose, marked with four black vittæ; wings grayish hyaline, hairs of veins black and with yellow ones as follows: on the bases and apices of the veins, on the first vein where the second issues from it, on the second vein where the third issues from it and at the point where it forks, on the fourth vein at the insertion of the cross-vein and also where this vein forks, and on the fifth vein where it forks; first submarginal cell nearly twice as long as its petiole, cross-vein at apex of second basal cell less than its length before the one above it ; tarsal claws of male each bearing two long, slender teeth on the under side, one near the base and the other near the middle, those of the female with a single tooth near the base of each; length, 3 to $4.5 \mathrm{~mm}$. Five males and one female. Type No. 6839, U. S. National Museum. 